1. Japan. Assoc. Min.

Petr, Econ Geol.

$68,259-267,1973$

\title{
COEXISTING OLIVINE AND PYROXENES FROM THE ACOJE ULTRAMAFICS, PHILIPPINES
}

\author{
TERUYUKI TAKedA and HrTOSHI ONUKI
}

Sumitomo Metal Mining Co., LTD, Tokyo, Japan

Institute of Mineralogy. Petrology and Economic Geology, Tohokti University, Sendai, Japan

Three selected peridotites, their olivines and pyroxenes from the Acoje mine, Philippines were chemically studied. From the data based on the pyroxene grid the Acoje peridotites seem to be recrystallized under conditions prevailing in the plagioclase peridotite field, and this estimation is not inconsistent with the suggestions : from the distribution coefficient data of $\mathrm{Fe}^{+2-\mathrm{Mg}}$ between the coexisting silicates in the peridotites.

\section{INTRODUCTION}

The Zambales Range in Luzon Island, Philippines, stretches southward from the western coast of the Lingayen Gulf to the Bataan Peninsula, occupying an area about $180 \times 35$ square $\mathrm{km}$. The Zambales Range is mainly composed of the ultramafic complex of which the age of emplacement is estimated to be Cretaceous. On the west of the Range, along the coast, the ultramafic belt is covered with unconformity by Miocene limestone, conglomerate, sandstone and marl, and on the east and south it is covered by volcanic rocks of Tertiary to Quarternary age. The Zambales ultramafic complex consists of dunite, peridotite and pyroxenite, which have suffered more or less serpentinization, together with gabbroic rocks.

The Zambales region is well known as the most productive area of chrome and nickel ores in the Philippines. The Acoje and Coto mines are being worked in this region. In the Acoje mine district ultrama- fic rocks are composed of dunite, peridotite,

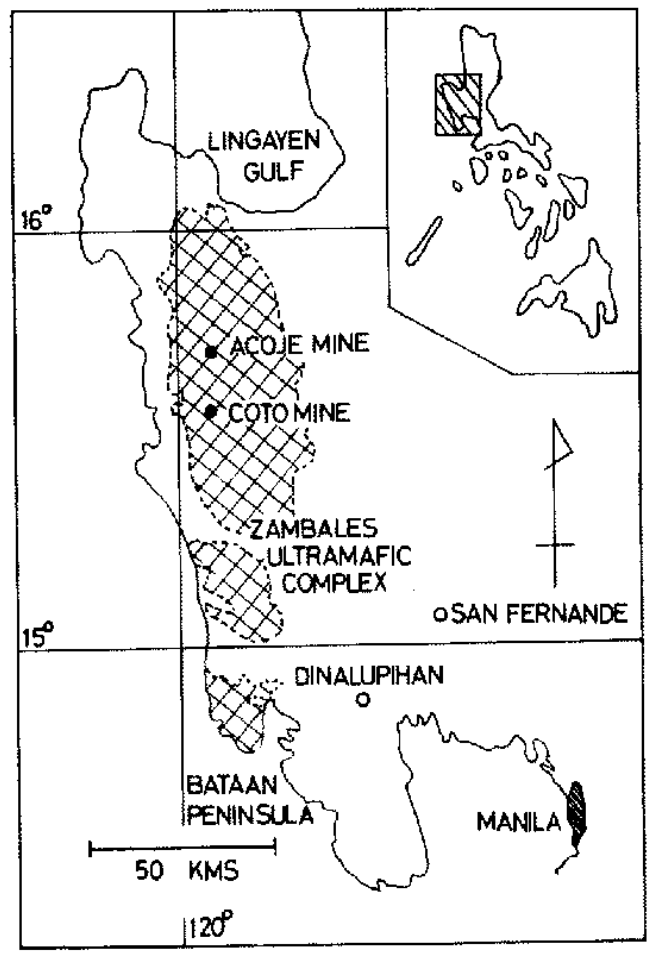

Fig. 1. Distribution of the Zambales ultramafic complex, Luzon Island, Philippines. 
pyroxenite and a small amount of gabbroic rocks. The ore deposits of chrome and nickel in these mines occur mainly in the dunite and peridotite. So far, the metallic minerals identified in the Acoje mine are chromite, pentlandtite, troilite, pyrite, chalcopyrite, awaruite, magnetite, hematite, violarite, native copper and goethite.

In this paper the chemistry of three selected peridotites, their olivines and coexisting pyroxenes from the Acoje mine is described, and some petrological discussions are given.

\section{Petrography}

Three selected specimens, each considerably serpentinized, but still retain sufficient amounts of primary constituents so that the original texture can be identified. Olivine is the most intensely altered, orthopyroxene is next and clinopyroxene usually remain intact. The modal compositions were obtained by point-counter analyses in which discrimination of the serpentine replacing olivine from that replacing orthopyroxene was carefully carried out. Rock nomenclature is used in accordance with the classification of Jackson (1968).

1) Serpentinized harzburgite (Specimen No. D-5-a).

The rock had originally an allotriomorphic-granular texture, with a maximum size up to $3 \mathrm{~mm}$ in length. It is primarily composed of olivine $(\mathrm{Nz}=1.672)$, orthopyroxene $\left(\mathrm{Ny}=1.667-1.688,2 \mathrm{Vz}=85^{\circ}-87^{\circ}\right)$, clinopyroxene $\left(\mathrm{Ny}=1.678-1.679,2 \mathrm{Vz}=54^{\circ}-56^{\circ}\right)$ and a little amount of yellowish brown chromite. Olivine shows sporadic development of undulose extinction. Orthopyroxene and clinopyroxene have very thin exsolution lamellae parallel to the (100) plane of the host crystal. The lamellae could not be identified, but may be Ca-rich and $\mathrm{Ca}$ - poor pyroxenes in the orthopyroxene and clinopyroxene, respectively. The primary modal composition (volume per cent), approximate because of the uncertainty of the presence of serpentine, is as follows: olivine 86 , orthopyroxene 10 , clinopyroxene 3 and chromite 1.

2) Serpentinized lherzolite (Sp. No. F-14).

The rocks is allotriomorphic-granular in texture with crystals less than $4 \mathrm{~mm}$ in size. Its primary constituents are olivine $(\mathrm{Nz}=1.672)$, orthopyroxene $(\mathrm{Ny}=1.665,2 \mathrm{Vz}$ $\left.=87^{\circ}\right)$, clinopyroxene $\left(\mathrm{Ny}=1.679,2 \mathrm{Vz}=54^{\circ}\right)$ and some yellowish brown chromite. Olvine sometimes display wavy extinction and weak translation lamellae. Both pyroxenes contain very thin lamellae. The approximate modal analysis of the original rock is olivine 83 per cent, orthopyroxne 9 per cent, clinopyroxene 7 per cent and chromite 1 per cent in volume.

Table 1. Chemical compositions of the ultramafic rocks from the Acoje mine.

\begin{tabular}{|c|c|c|c|}
\hline & $\begin{array}{c}1 \\
D-5-a \\
\end{array}$ & $\begin{array}{c}2 \\
F-14 \\
\end{array}$ & $\begin{array}{c}3 \\
1-1 \\
\end{array}$ \\
\hline $\mathrm{SiO}_{2}$ & 39.63 & 39.74 & 47.47 \\
\hline $\mathrm{TiO}_{2}$ & 0.14 & 0.19 & 0.19 \\
\hline $\mathrm{Al}_{2} \mathrm{O}_{3}$ & 2.03 & 1.42 & 1.26 \\
\hline $\mathrm{Cr}_{2} \mathrm{O}_{3}$ & 0.29 & 0.24 & 0.28 \\
\hline $\mathrm{Fe}_{2} \mathrm{O}_{3}$ & 5.67 & 5.19 & 2.61 \\
\hline $\mathrm{FeO}$ & 2.82 & 3.32 & 2.73 \\
\hline $\mathrm{MnO}$ & 0.12 & 0.12 & 0.11 \\
\hline $\mathrm{NiO}$ & 0.34 & 0.32 & 0.12 \\
\hline $\mathrm{MgO}$ & 38.62 & 38.53 & 23.96 \\
\hline $\mathrm{CaO}$ & 0.37 & 1.50 & 15.06 \\
\hline $\mathrm{Na}_{2} \mathrm{O}$ & 0.01 & 0.01 & 0.18 \\
\hline $\mathrm{K}_{2} \mathrm{O}$ & tr. & tx. & 0.01 \\
\hline $\mathrm{H}_{2} \mathrm{O}+$ & 9.42 & 8.20 & 5.49 \\
\hline $\mathrm{H}_{2} \mathrm{O}-$ & 0.32 & 1.05 & 0.64 \\
\hline $\mathrm{P}_{2} \mathrm{O}_{5}$ & tr. & tr. & tr. \\
\hline Total & 99.78 & 99.82 & 100.14 \\
\hline$M *$ & 89.6 & 89.5 & 89.2 \\
\hline
\end{tabular}


3) Serpentinized wehrlite (Sp. No. L-1).

This shows a typically hypidiomorphicgranular texture, ranging 5 to $1 \mathrm{~mm}$ in diameter. The primary minerals are clinopyroxene $\left(\mathrm{Ny}=1.680,2 \mathrm{Vz}=53^{\circ}\right)$, olivine $(\mathrm{Nz}=$ $1.675)$, orthopyroxene $\left(\mathrm{Ny}=1.669,2 \mathrm{Vz}=88^{\circ}\right)$ and a little amount of yellowish brown chromite. Olivine and both pyroxenes sporadically show undulating extinction. Exsolution lamellae of clinopyroxene and orthopyroxene in orthopyroxene and clinopyroxene, respectively, are developed along (100) the host crystal. The volumetric percentage of the original constituent minerals in this rock are clinopyroxene 68 , olivine 27 and orthopyroxene 5 .

\section{Bulk Rock Chemistry and Serpent- INIZATION}

The bulk chemical compositions of three serpentinized peridotites are presented in Table 1. If, as the first approximation, the serpentinization in the Acoje ultramafics have proceeded by the simple addition of water without leaching of any oxides, the estimation of the modal composition concerning olivine and pyroxenes could be possible from the $\left(\mathrm{Mg}+\mathrm{Ni}+\mathrm{Fe}^{+2}+\mathrm{Fe}^{+3}+\mathrm{Mn}\right) /$ Si ratio of the host rock, because these ratios of the olivine and pyroxenes from the ultramafic intrusive rocks are almost two and unit, respectively. The computed modal compositions (volume per cent) based on this method are as follows:

D-5-a olivine 64, pyroxenes 36.

F-14 olivine 66, pyroxenes 34 .

I-1 olivine 34 , pyroxenes 66 .

Even though the uncertainty of the observed modal analysis is taken into consideration, it can be said that comparison between the observed and calculated modal compositions shows considerable discrepancy. In addition, $\mathrm{Al}_{2} \mathrm{O}_{3}$ content of each of the analysed rocks is not consistent with the assumed amount of $\mathrm{Al}_{2} \mathrm{O}_{3}$ by means and either of the two modal analyses noted already. These evidences may show the chemical complexity of the serpentinization

Table 2. Olivine analyses.

\begin{tabular}{|c|c|c|c|c|c|c|c|}
\hline & \multicolumn{3}{|c|}{ Weight per cent } & \multicolumn{4}{|c|}{ Atomic ratios, when $0=4$} \\
\hline & $\begin{array}{c}1 \\
D-5-a \\
\end{array}$ & $\begin{array}{c}2 \\
F-14\end{array}$ & $\begin{array}{c}3 \\
1-1 \\
\end{array}$ & & $\frac{1}{D-5}-a$ & $\begin{array}{c}2 \\
E-14\end{array}$ & $\begin{array}{c}3 \\
1-1\end{array}$ \\
\hline $\mathrm{SiO}_{2}$ & 40.74 & 40.62 & 40.26 & Si & 0.999 & 1.000 & 0.997 \\
\hline $\mathrm{TiO}_{2}$ & 0.01 & 0.02 & 0.03 & A1 & 0.001 & - & 0.001 \\
\hline $\mathrm{Al}_{2} \mathrm{O}_{3}$ & 0.05 & tr. & 0.02 & & & & \\
\hline $\mathrm{Cr}_{2} \mathrm{O}_{3}$ & 0.03 & 0.01 & 0.01 & $\mathrm{Ti}$ & - & - & 0.001 \\
\hline $\mathrm{Fe}_{2} \mathrm{O}_{3}$ & 0.24 & 0.15 & 0.14 & $\mathrm{Cr}$ & 0.001 & - & - \\
\hline $\mathrm{FeO}$ & 9.59 & 10.14 & 10.75 & $\mathrm{Fe}^{+3}$ & 0.004 & 0.003 & 0.003 \\
\hline Mno & 0.12 & 0.15 & 0.14 & $\mathrm{Fe} e^{+2}$ & 0.197 & 0.209 & 0.222 \\
\hline $\mathrm{NiO}$ & 0.39 & 0.37 & 0.30 & $\mathrm{Pin}$ & 0.003 & 0.003 & 0.003 \\
\hline $\mathrm{MgO}$ & 48.78 & 48.42 & 47.91 & $\mathrm{Ni}$ & 0.008 & 0.007 & 0.006 \\
\hline $\mathrm{CaO}$ & 0.06 & 0.04 & 0.03 & $\mathrm{Mg}$ & 1.783 & 1.775 & 1.767 \\
\hline $\mathrm{Na}_{2} \mathrm{O}$ & $\operatorname{tr}$. & n.d. & n.d. & $\mathrm{Ca}$ & 0.002 & 0.001 & 0.001 \\
\hline $\mathrm{K}_{2} \mathrm{O}$ & $\mathrm{tr}$. & n.d. & n.d. & $\mathrm{Na}$ & - & - & - \\
\hline $\mathrm{H}_{2} \mathrm{O}+$ & 0.07 & 0.03 & 0.06 & $\mathrm{~K}$ & - & - & - \\
\hline $\mathrm{H}_{2} \mathrm{O}-$ & 0.05 & 0.02 & 0.03 & Total & 2.998 & 2.998 & 3.001 \\
\hline Tota 1 & 100.17 & 99.97 & 99.72 & $\mathrm{M}^{*}$ & 89.8 & 89.3 & 88.6 \\
\hline
\end{tabular}


of the ultramafics. It may be not really useful to compare the analyses of the ultramafics from different geologic environments with different degree of serpentinization. Compelled by the circumstance which Alpine type ultramafics are commonly partially or completely serpentinized, we usually carry out such a comparison. Practically it has some utility values. If the serpentinization of the ultramafic rocks is accompanied by minimal changes in the ratio of $(\mathrm{Mg}+\mathrm{Ni}) \times$ $100 /\left(\mathrm{Mg}+\mathrm{Ni}+\mathrm{Fe}^{+2}+\mathrm{Fe}^{+3}+\mathrm{Mn}\right)$, a comparison of the ratio can be made for various ultramafic intrusives. There is a small difference in the $(\mathrm{Mg}+\mathrm{Ni}) \times 100 /\left(\mathrm{Mg}+\mathrm{Ni}+\mathrm{Fe}^{+2}+\right.$ $\mathrm{Fe}^{+2}+\mathrm{Mn}$ ) ratio, ranging from 89.6 to 89.2 of the analysed rocks. These values are rather lower than those of the rocks from the Horoman (Onuki, 1965; Nagasaki, 1966) and Burro Mountain (Loney et al., 1971) ultramafic bodies, but are comparative with those from the Lizard peridotites (Green, 1964).

\section{Mineral Chemistry}

1) Olivine

The chemical composition and structural formula of the olivine from the serpentinized harzburgite, therzolite and wehrlite are listed in Table 2 . Their compositions are restricted to Fo values, $(\mathrm{Mg}+\mathrm{Ni}) \times 100 /(\mathrm{Mg}$ $+\mathrm{Ni}+\mathrm{Fe}^{+2}+\mathrm{Fe}^{+3}+\mathrm{Mn}$ ), from 89.8 to 88.6 . The Fo contents of the olivines from the Acoje peridotites are similar, in general, to those from many Alpine-peridotites and peridotite inclusions in basaltic rocks. But these values fall within the less magnesian part of the range of olivines from Alpineperidotites and olivine nodules.

Forbes and Banno (1966) suggested that the $\mathrm{Ni}-\mathrm{Fe}$ ratio of olivine differs according to their mode of occurrence. Nakamura (1971) has also shown that the olivines from the Toba ultramafic complex (Nakamura, 1971) and dunite-wehrlite series inclusions in Hawaii (White, 1966) have different NiO-

Table 3. Orthopyroxene analyses.

\begin{tabular}{|c|c|c|c|c|c|c|c|}
\hline \multicolumn{4}{|c|}{ Weight per cent } & \multicolumn{4}{|c|}{ Atomic ratios, when $0=6$} \\
\hline & $\begin{array}{c}1 \\
D-5-a \\
\end{array}$ & $\begin{array}{c}2 \\
F-14 \\
\end{array}$ & $\begin{array}{c}3 \\
L-1 \\
\end{array}$ & & $\begin{array}{c}1 \\
D-5-a \\
\end{array}$ & $\begin{array}{c}2 \\
F-14 \\
\end{array}$ & $\begin{array}{c}3 \\
2-1 \\
\end{array}$ \\
\hline $\mathrm{SiO}_{2}$ & 55.99 & 55.74 & 55.49 & $\mathrm{Si}$ & 1.938 & 1.936 & 1.929 \\
\hline $\mathrm{TiO}_{2}$ & 0.15 & 0.19 & 0.21 & Al IV & 0.062 & 0.064 & 0.071 \\
\hline $\mathrm{A} 1{ }_{2} \mathrm{O}_{3}$ & 2.81 & 2.92 & 3.27 & $A 1^{V I}$ & 0.053 & 0.055 & 0.063 \\
\hline $\mathrm{Cr}_{2} \mathrm{O}_{3}$ & 0.50 & 0.25 & 0.24 & $\mathrm{Ti}$ & 0.004 & 0.005 & 0.005 \\
\hline $\mathrm{Fe}_{2} \mathrm{O}_{3}$ & 0.39 & 0.43 & 0.34 & $\mathrm{Cr}$ & 0.014 & 0.008 & 0.007 \\
\hline $\mathrm{FeO}$ & 6.01 & 6.31 & 6.55 & $\mathrm{Fe}^{+3}$ & 0.010 & 0.011 & 0.009 \\
\hline Mno & 0.14 & 0.14 & 0.15 & $\mathrm{Fe}^{+2}$ & 0.174 & 0.183 & 0.190 \\
\hline $\mathrm{NiO}$ & 0.10 & 0.08 & 0.08 & Mn & 0.004 & 0.004 & 0.004 \\
\hline $\mathrm{MgO}$ & 32.98 & 32.68 & 32.61 & $\mathrm{Ni}$ & 0.003 & 0.002 & 0.002 \\
\hline $\mathrm{CaO}$ & 0.74 & 0.78 & 0.48 & $\mathrm{Mg}$ & 1.701 & 1.691 & 1.689 \\
\hline $\mathrm{Na}_{2} \mathrm{O}$ & 0.02 & 0.03 & 0.07 & $\mathrm{Ca}$ & 0.027 & 0.029 & 0.018 \\
\hline $\mathrm{K}_{2} \mathrm{O}$ & tr. & tr. & tr. & $\mathrm{Na}$ & 0.001 & 0.002 & 0.005 \\
\hline $\mathrm{H}_{2} \mathrm{O}+$ & 0.05 & 0.07 & 0.07 & $\mathrm{~K}$ & - & - & - \\
\hline $\mathrm{H}_{2} \mathrm{O}^{-}$ & 0.10 & 0.05 & 0.05 & Total & 3.991 & 3.990 & 3.992 \\
\hline Total & 99.98 & 99.67 & 99.61 & $M^{*}$ & 90.1 & 89.5 & 89.3 \\
\hline
\end{tabular}


$(\mathrm{Fe} \times 100 / \mathrm{Mg}+\mathrm{Fe})$ ratio from those from other ultramafic intrusions in orogenic belts. The former group is interpreted to have accumulated from a basaltic magma in genesis (White, 1966; Nakamura, 1971). Analysed olivines from the Acoje ultramafics fall within the range of olivines from ultramafic intrusions in orogenic belts.

\section{2) Orthopyroxene}

The chemical analyses and calculated atomic ratios of the orthopyroxenes from three Acoje peridotites are given in Table 3. The orthopyroxenes have a range of 90.1 to 89.3 in $(\mathrm{Mg}+\mathrm{Ni}) \times 100 /\left(\mathrm{Mg}+\mathrm{Ni}+\mathrm{Fe}^{+2}+\mathrm{Mn}\right)$

Table 4. Molecular proportions of orthopyroxenes.

\begin{tabular}{l|r|r|r}
\hline & \multicolumn{1}{|c|}{$\begin{array}{c}1 \\
\mathrm{D}-5-\mathrm{a}\end{array}$} & \multicolumn{1}{|c}{$\mathrm{F}-14$} & \multicolumn{1}{c}{$\mathrm{L}-1$} \\
\hline $\mathrm{NaCrSi}_{2} \mathrm{O}_{6}$ & 0.1 & 0.2 & 0.5 \\
$\mathrm{CaTiA2}_{2} \mathrm{O}_{6}$ & 0.4 & 0.5 & 0.5 \\
$\mathrm{MgCrA1SiO}_{6}$ & 1.3 & 0.6 & 0.4 \\
$\mathrm{MgFe}^{+3} \mathrm{AlSiO}_{6}$ & 1.0 & 1.2 & 1.0 \\
$\mathrm{MgAl}_{2} \mathrm{SiO}_{6}$ & 4.3 & 4.7 & 5.7 \\
$\mathrm{MgSiO}_{3}$ & 82.7 & 82.2 & 82.4 \\
$\mathrm{CaSiO}_{3}$ & 1.2 & 1.2 & 0.7 \\
$\mathrm{FeSiO}_{3}$ & 9.0 & 9.5 & 8.8 \\
\hline
\end{tabular}

ratio. $\mathrm{Al}_{2} \mathrm{O}_{3}$ ranges from 2.81 to 3.27 weight per cent. The $\mathrm{Al}_{2} \mathrm{O}_{3}$ contents of the Acoje orthopyroxenes are similar to those from the New Zealand peridotites (Challis, 1965) and are higher than those of the Burro Mountain peridotites (Loney et al., 1971), but lower than those of the ultramafics from the Lizard (Green, 1964), Horoman (Onuki, 1965; Nagasaki, 1966) and typical peridotites in southwestern Oregon (Medaris, 1972).

Because the orthopyroxenes from the Acoje peridotites have relatively lower $\mathrm{Al}_{2} \mathrm{O}_{3}$ contents, the analysis in detail on the role of $\mathrm{Al}_{2} \mathrm{O}_{3}$ in them may be not significant. It can be pointed out, however, that the variation of $\mathrm{Al}_{2} \mathrm{O}_{3}$ contents in these ortho- pyroxenes is not dependant on pressure differences, but on the varying availability of $\mathrm{Al}_{2} \mathrm{O}_{3}$. The $\mathrm{CaO}$ contents of the orthopyroxenes ranges from 0.45 to 0.78 weight per cent, which is much lower than values for orthopyroxenes from many other ultramafic intrusives (Green, 1964; Onuki, 1965; Nagasaki, 1966; Loney et al., 1971; Medaris, 1972), though they have very thin exsolution lamellae of $\mathrm{Ca}$-rich pyroxene.

Molecular proportaions calculated by the method after Kushiro (1962), and Onuki and Tiba (1965) are shown in Table 4. $\mathrm{Mg}$ Tschermak's molecules show a relatively stnall range (4.3-5.7 per cent). The values are slightly higher than those of the Horoman ultramafics (Onuki, 1965; Nagasaki, 1966) and lower than those of the Lizard peridotite (Green, 1964).

3) Clinopyroxene

The three clinopyroxenes coexisting with the analysed olivine and orthopyroxene were also analysed by the wet chemical method (Table 5). They fall close to the boundary between endiopside and diopside in the system $\mathrm{CaMgSi}_{2} \mathrm{O}_{6}-\mathrm{CaFeSi}_{2} \mathrm{O}_{6}-\mathrm{Mg}_{2} \mathrm{Si}_{2}$ $\mathrm{O}_{6}-\mathrm{Fe}_{2} \mathrm{Si}_{2} \mathrm{O}_{6}$. The $\mathrm{Cr}_{2} \mathrm{O}_{3}$ content of the clinopyroxene is always higher than that of the coexisting orthopyroxene. In the analysed clinopyroxenes, $\mathrm{Al}_{2} \mathrm{O}_{3}, \mathrm{TiO}_{2}, \mathrm{MnO}$ and $\mathrm{Na}_{2} \mathrm{O}$ tend to increase with decreasing $(\mathrm{Mg}+$ $\mathrm{Ni} \times 100 /\left(\mathrm{Mg}+\mathrm{Ni}+\mathrm{Fe}^{+2}+\mathrm{Fe}^{+3}+\mathrm{Mn}\right)$ ratio, but the $\mathrm{Cr}_{2} \mathrm{O}_{3}$ content shows just the reverse trend.

The amounts of $\mathrm{Al}_{2} \mathrm{O}_{3}$ (2.91-3.28 weight per cent) in them are higher than those from Dawros (Rothstein, 1958), Hayachine (Onuki, 1963), Kanto Mountains (Tazaki, 1967) and Burro Mountain (Loney et al., 1971) peridotites, and are lower than those of the primary peridotites from Lizard (Green, 1964) and of the peridotites from Horoman (Onuki, 1965; Nagasaki, 1966) 
Table 5. Clinopyroxene analyses.

\begin{tabular}{|c|c|c|c|c|c|c|c|}
\hline & \multicolumn{3}{|c|}{ Weight per cent } & \multicolumn{4}{|c|}{ Atomic ratios, when $0=6$} \\
\hline & $\begin{array}{c}1 \\
D-5-a\end{array}$ & $\begin{array}{c}2 \\
F-14 \\
\end{array}$ & $\begin{array}{c}3 \\
L-1 \\
\end{array}$ & & $\begin{array}{c}1 \\
D-5-a\end{array}$ & $\begin{array}{c}2 \\
F-14 \\
\end{array}$ & $\begin{array}{c}3 \\
L-1 \\
\end{array}$ \\
\hline $\mathrm{SiO}_{2}$ & 52.31 & 52.50 & 52.65 & Si & 1.907 & 1.900 & 1.916 \\
\hline $\mathrm{TiO}_{2}$ & 0.15 & 0.17 & 0.18 & $\mathrm{Al}{ }^{\mathrm{IV}}$ & 0.093 & 0.100 & 0.084 \\
\hline $\mathrm{AI}_{2} \mathrm{O}_{3}$ & 2.91 & 3.06 & 3.28 & $\mathrm{Al}^{\mathrm{VI}}$ & 0.032 & 0.030 & 0.057 \\
\hline $\mathrm{Cr}_{2} \mathrm{O}_{3}$ & 1.03 & 0.39 & 0.39 & $\mathrm{Ti}$ & 0.004 & 0.005 & 0.005 \\
\hline $\mathrm{Fe}_{2} \mathrm{O}_{3}$ & 1.03 & 1.12 & 0.99 & $\mathrm{Cr}$ & 0.030 & 0.011 & 0.011 \\
\hline FeO & 2.15 & 2.31 & 2.21 & $\mathrm{Fe}^{+3}$ & 0.028 & 0.030 & 0.027 \\
\hline Mno & 0.08 & 0.09 & 0.09 & $\mathrm{Fe}^{+2}$ & 0.064 & 0.070 & 0.067 \\
\hline MgO & 17.56 & 18,46 & 17.07 & $M n$ & 0.002 & 0.003 & 0.003 \\
\hline $\mathrm{CaO}$ & 22.41 & 22.06 & 22.64 & $\mathrm{Mg}$ & 0.954 & 0.995 & 0.925 \\
\hline $\mathrm{Na}_{2} \mathrm{O}$ & 0.16 & 0.25 & 0.34 & $\mathrm{Ca}$ & 0.875 & 0.855 & 0.882 \\
\hline $\mathrm{K}_{2} \mathrm{O}$ & $\operatorname{tr}$. & 0.02 & 0.02 & $\mathrm{Na}$ & 0.011 & 0.017 & 0.024 \\
\hline $\mathrm{H}_{2} \mathrm{O}+$ & 0.05 & $\pm r$. & 0.05 & $K$ & - & 0.001 & 0.001 \\
\hline $\mathrm{H}_{2} \mathrm{O}-$ & 0.11 & 0.05 & 0.07 & Tota 1 & 4.000 & 4.017 & 4.002 \\
\hline Total & 99.98 & 300.08 & 99.98 & $\mathrm{Ca}$ & 45.5 & 43.8 & 46.3 \\
\hline \multirow{2}{*}{$M^{*}$} & \multirow{2}{*}{90.9} & \multirow{2}{*}{90.6} & \multirow{2}{*}{90.4} & $\mathrm{Mg}$ & 49.5 & 50.9 & 46.6 \\
\hline & & & & $\mathrm{Fe}^{* *}$ & 5.0 & 5.3 & 5.1 \\
\hline
\end{tabular}

$* \mathrm{M}=\mathrm{Mg} \times 100 /\left(\mathrm{Mg}+\mathrm{Fe}^{+2}+\mathrm{Fe}^{+3}+\mathrm{Mn}\right), \quad * * \mathrm{Fe}=\mathrm{Fe}^{+2}+\mathrm{Fe}^{+3}+\mathrm{Mn}$

(Analyst: H. Onuki)

Table 6. Molecular proportions of clinopyroxenes.

\begin{tabular}{l|c|c|c}
\hline & $\begin{array}{c}1 \\
0-5-a\end{array}$ & $\begin{array}{c}2 \\
F-14\end{array}$ & $\begin{array}{c}3 \\
\text { L-1 }\end{array}$ \\
\hline $\mathrm{NaCrSi}_{2} \mathrm{O}_{6}$ & 1.1 & 1.1 & 1.1 \\
$\mathrm{NaFe}^{+3} \mathrm{Si}_{2} \mathrm{O}_{6}$ & - & 0.7 & 1.4 \\
$\mathrm{CaCrAlSiO}_{6}$ & 1.9 & - & - \\
$\mathrm{CaTiAl}_{2} \mathrm{O}_{6}$ & 0.4 & 0.5 & 0.5 \\
$\mathrm{CaFe}^{+3} \mathrm{AlSiO}_{6}$ & 2.8 & 2.3 & 1.3 \\
$\mathrm{CaAl}_{2} \mathrm{SiO}_{6}$ & 3.5 & 4.7 & 5.9 \\
$\mathrm{CaSiO}_{3}$ & 39.6 & 38.3 & 40.1 \\
$\mathrm{MgSiO}_{3}$ & 47.4 & 48.8 & 46.2 \\
$\mathrm{FeSiO}_{3}$ & 3.3 & 3.6 & 3.5 \\
\hline
\end{tabular}

and southwestern Oregon (Medaris, 1972). This range of $\mathrm{Al}_{2} \mathrm{O}_{3}$ contents of the clinopyroxenes is comparable with those of peridotites from New Zealand (Challis, 1966) and of recrystallized peridotites in the Lizard area (Green, 1964).

Molecular proportions calculated based on the method after Kushiro (1962) of the analysed clinopyroxenes from the Acoje ultramafics are shown in Table 6. The jadeite molecule is absent in them, but the $\mathrm{CaAl}_{2} \mathrm{SiO}_{8}$ component ranges from 3.5 to 5.9 per cent.

\section{DISTRIBUTION OF $\mathrm{Fe}^{+2}-\mathrm{Mg}$ BeTWEEN COEXISTING SILICATES}

The distribution of $\mathrm{Fe}^{+2}$ and $\mathrm{Mg}$ be tween the coexisting mineral pairs, olivineorthopyroxene, olivine-clinopyroxene and orthopyroxene-clinopyroxene from the Acoje peridotites is examined here.

\section{1) Olivine-orthopyroxene}

Recently Nafziger and Muan (1967), Larimer (1968) and Medaris (1969) studied experimentally the $\mathrm{Fe}^{+2}-\mathrm{Mg}$ distribution between olivine and orthopyroxene. The distribution coefficient, $\left(\mathrm{Fe}^{+2} / \mathrm{Mg}\right)$ ol $/\left(\mathrm{Fe}^{+2} / \mathrm{Mg}\right)$ opx, is not so sensitive to change in temperature over the range $700^{\circ}$ to $1300^{\circ} \mathrm{C}$ (Larimer, 1968; Medaris, 1969). Olivine-orthopyroxene pairs of the Acoje peridotites yield the 
distribution function of $1.08-1.11$ and plot on the high temperature side of the distribution curve determined experimentally at $900^{\circ} \mathrm{C}$ and 500 bars pressure (Medaris, 1969).

Nafziger and Muan (1967) have shown that olivine solid solution has a moderate deviation from ideality, whereas the pyroxene solid solution is practically ideal in its activity-composition relation. Using activity coefficient data at $1200^{\circ} \mathrm{C}$ determined by Nafziger and Muan (1967), and the following equation,

$$
\begin{aligned}
& \mathrm{K}= \frac{\left[\mathrm{Fe}^{+2} /\left(\mathrm{Mg}+\mathrm{Fe}^{+2}\right)\right] \mathrm{ol} \cdot \gamma_{\mathrm{Fe}^{+2}}{ }^{\mathrm{ol}}}{\left[\mathrm{Mg} /\left(\mathrm{Mg}+\mathrm{Fe}^{+2}\right)\right] \mathrm{ol} \cdot \gamma_{\mathrm{Mg}^{\mathrm{ol}}}} / \\
& \frac{\left[\mathrm{Mg} /\left(\mathrm{Mg}+\mathrm{Fe}^{+2}\right)\right] \mathrm{opx} \cdot \gamma_{\mathrm{Mg}}{ }^{\mathrm{opx}}}{\left[\mathrm{Fe}^{+2} /\left(\mathrm{Mg}+\mathrm{Fe}^{+2}\right)\right] \mathrm{opx} \cdot \gamma_{\mathrm{F}^{+}}{ }^{\mathrm{O}^{\mathrm{opx}}}}
\end{aligned}
$$

where the $\gamma$ values with appropriate subscrips and super scripts are the activity coefficients. The $K$ values around $1.55 \pm 0.05$ of three pairs from the Acoje peridotites are obtained.

Williams and Eugster (1969), however, have demonstrated that the distribution of iron and magnesium between these two minerals is not dependant of temperature. If it is so, the distribution coefficient of $\mathrm{Fe}^{+2}$ and $\mathrm{Mg}$ can not used as a geothermometer.

\section{2) Olivine-clinopyroxene}

The distribution coefficient of $\mathrm{Fe}^{+2}$ and $\mathrm{Mg}$, that is, $\mathrm{K}=\left(\mathrm{Fe}^{+2} / \mathrm{Mg}\right)_{\mathrm{ol}} /\left(\mathrm{Fe}^{+2} / \mathrm{Mg}\right)_{\mathrm{cpx}}$, between the coexisting olivine and clinopyroxene from the Acoje peridotites ranges from 1.65 to 1.73 . These values are similar to those from the Miyamori ultramafic complex (Onuki, 1965), but slightly higher than the Lizard ultramafic complex (Green, 1964) and Horoman ultramafic mass (Onuki, 1965; Nagasaki, 1966) and the high-pressure type peridotites in southwestem Oregon (Medaris, 1972).

3) Orthopyroxene-clinopyroxene

The coexisting pyroxenes from the Aco-

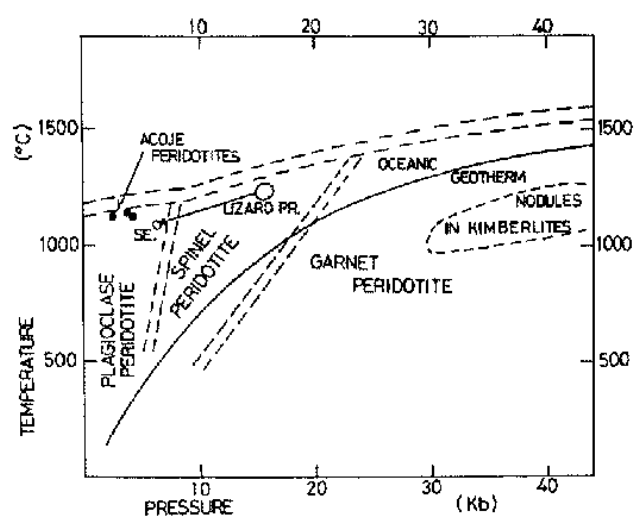

Fig. 2. P-T conditions for the Acoje peridotites based on O'Hara's pyroxene grid.

Lizard PR.: Primary peridotites from Lizard (Green, 1964).

SE. : Secondary (recrystallized) peridotites from Lizard (Green, 1964).

je peridotites have $K$ values, namely $K=$ $\left(\mathrm{Fe}^{+2} / \mathrm{Mg}\right)_{\text {OPX }} /\left(\mathrm{Fe}^{+2} / \mathrm{Mg}\right)_{\mathrm{CPX}}$, that ranges from 1.52 to 1.55 , which is within analytical error. Kretz (1961), Bartholemé (1962) have shown that $\mathrm{K}$ is about 1.4 is igneous rocks and 1.8 in metamorphic rocks. The obtained values from the Acoje peridotites are comparable with those of igneous origin, but these values suggest that the peridotites were formed at relatively lower temperatures.

\section{Petrogenetic Grid Based on Cli- NOPYROXENE COMPOSITION}

Green and Ringwood (1967) have indicated that natural peridotites with sufficient $\mathrm{Al}_{2} \mathrm{O}_{3}$ occur in three distinct mineral facies under anhydrous conditions, that is, 1) plagioclase peridotite, 2) spinel peridotite and 3) garnet peridotite. O'Hara (1967) has proposed a provisional P-T projection and their bounding equilibria for natural aluminous four-phase peridotites, usuing the chemical properties of clinopyroxene. Fig. 2 shows the pressure-temperature conditions for the Acoje peridotites based on O'Hara's 
pyroxene grid. Clinopyroxene compositions from the Acoje peridotites plot in the plagioclase peridotite field and their host rocks appear to have equilibrated under conditions within the range from 2 to $4 \mathrm{~kb}$ around $1100^{\circ}-1200^{\circ} \mathrm{C}$. These inferred conditions of equilibrium suggest that Acoje peridotites were recrystallized at a high temperature within the plagioclase peridotite field.

\section{ConCLUSION}

The bulk and mineral chemistries do not directly give good ground for the discussion on the genesis of the Acoje peridotites. As regards the chemical nature of the pyroxenes, however, it can be said that these peridotites were not formed under the conditions of higher pressures. The interpretation of distribution coefficient between $\mathrm{Fe}^{+2}$ and $\mathrm{Mg}$ for the coexisting silicate minerals used here includes many uncertainties, and it is too qualitative at present. Thus, O'Hara's pyroxene grid is a tool only useful for the estimation of the physical condition where the Acoje peridotites were crystallized or recrystallized.

From the data based on the pyroxene grid the Acoje peridotites seem to be recrystallized under conditions prevailing in the plagioclase peridotite field, and this estimation is not inconsistent with the suggestions from the distribution coefficient data of $\mathrm{Fe}^{+2}$ and $\mathrm{Mg}$ between the coexisting silicates in the peridotites. If it is so, the diapiric movement of the Acoje peridotites from deep in the crust or the upper mantle to a shallower level in the crust could have occurred. It is uncertain whether partial melting of the peridotites occurred during hot diapiric movement. No plagioclase in the present recrystallized peridotites should depend on their chemical character poor in $\mathrm{Al}_{2} \mathrm{O}_{3}$.

\section{ACKNOWLEDGEMENTS}

The authors wish to express their thanks to Professor Tsunehiko Takeuchi of the Tohoku University for his kind guidance and constant encouragement. Sincere appreciation is extended to Professor Kotora Hatai of the Tohoku University for his critical reading of the manuscript.

\section{REFERENCES}

Bartholemé, P. (1962) Iron-magnes'um ratio in associated pyroxenes and olvines. In: Petrologic studies (Engel, A.E.J., James, H.L., Leonard, B.F. ed.), Geol. Soc. Am., Buddington volume, 1-20.

Challis, G.A. (1965) The origin of New Zealand ultramafic intrusions. Jous. Petrol., 6, 322364.

Forbes, R.B., Banno, S. (1966) Nickel-iron content of peridotite inclusion and cognate olivine from an alkali-olivine basalt. Am. Min. 51, 130-140.

Green, D.H. (1964) The petrogenesis of the hightemperature peridotite intrusion in the Lizard area, Cornwall. Jour. Petrol., 5, 124-188.

field of aluminous pyroxene peridotite and garnet peridotite and their relevance in upper mantle structure. Eavth Planet. Sci. Letters, 3. 151-160.

Jackson, E.D. (1968) The character of the lower crust and upper mantle beneath the Hawaiian Island. Inter. Nat. Geol. Congr., 23rd Session, Czechoslovakia, 1, 135-150.

Kretz, R. (1961) Some application of thermodynacmis to coexisting minerals of variable composition - Examples, orthopyroxene-clinopyroxene and orthopyroxene-garnet. Jour. Geol., 69, 361-387.

Kushiro, I. (1962) Clinopyroxene solid solutions. Part 1. The $\mathrm{CaAl}_{2} \mathrm{SiO}_{6}$ component. Japan. Jour. Geol. Geogr., 33, 213-220.

Larimer, J.W. (1962) Experimental studies on the system $\mathrm{Fe}-\mathrm{MgO}-\mathrm{SiO}_{2}-\mathrm{O}_{2}$ and their bearing on the petrology of chondritic meteorities. Geochim. Cosmochim. Acta, 32, 1187-1207.

Loney, R., Himmelberg, G.R., Coleman, R.G. (1971) Structure and petrology of the Alpinetype peridotite at Burro Mountain, California, U.S.A. Jour. Petrol., 12, 245-310.

Medaris, L.G. (1969) Partitioning of $\mathrm{Fe}^{++}$and $\mathrm{Mg}^{++}$between coexisting synthetic olivine and orthopyroxene. Am, Jour. Sci., 267, 945-968. 
(1972) High-pressure peridotites in southwestern Oregon. Geol. Soc. Am., Bull., 83, $41-58$.

Nafziger, R.H., Muan, A. (1967) Equilibrium phase compositions and thermodynamic properties of olivines and pyroxenes in the system $\mathrm{MgO}^{*} \mathrm{FeO}^{\prime}-\mathrm{SiO}_{2}$. Am. Min., 52, 1364-1385.

Nagasaki, H. (1966) A layered ultrabasic complex at Horoman, Hokkaido, Japan. Jour. Fac. Sci., Univ. Tokyo, Sec. II, 16, 313-346.

Nakamura, Y. (1971) Petrology of the Toba ultrabasic complex, Mie Prefecture, central Japan. Jour. Fac. Sci., Univ. Tokyo, Sec. II, 18, 1-51.

OHara, M.J. (1967) Mineral paragenesis in ultrabasic rocks, In: Ultramafic and related rocks (Wyllie, P.J. ed.). New York, John Wiley \& Sons, Inc., 393-402.

Onuki, H. (1963) Petrology of the Hayachine vitramafic complex in the Kitakami mountainland, northern Japan. Sci. Rep. Tohoku Uniw., Ser. III, 8, 241-296.

(1965) Petrochemical research on the Horoman and Miyamori ultramafic intrusives, northern Japan. Sci. Rep. Tohoku Univ., Ser. $I I I, 9,217-276$.

- Tiba, T. (1965) Notes on petrochemistry of ultramafic intrusives - specially, aluminium distribution in co-existing pyroxenes. Jour. Japan. Assoc. Min. Petr. Econ. Geol., 53, 215-227.

Rothstein, A.T.V. (1958) Pyroxenes from the Dawros peridotite and some comments on their nature. Geol. Mag., 95, 456 462.

Tazaki, K. (1967) Clinopyroxene of the ultrabasic rocks in the northern Kwanto mountains, cent ral Japan. Jour. Japan. Assoc. Min. Petr. Econ. Geol., 57, 137-144 (in Japanese).

White, R.W. (1966) Ultramafic inclusions in basaltic rocks from Hawaii. Contr. Min. Petrol., 12. $245-314$.

Williams, R.J., Eugster, H.P. (1969) An experimental study of ( $\mathrm{Fe}, \mathrm{Mg}$ ) olivine - $(\mathrm{Fe}, \mathrm{Mg})$ pyroxene relations and their geological applications. Geol. Soc. Am. Abstract for 1969, Part 7, 239 (abstract).

\section{フィリッピン, Acoje かんらん岩類に共存するかんらん石と輝石類}

武田 晃幸·大貫 壬

フィリッピン群島，ルソン島に広く分有する Zambales 超苦鉄質岩体のうち，Acoje 鉱山付近より，3 種の

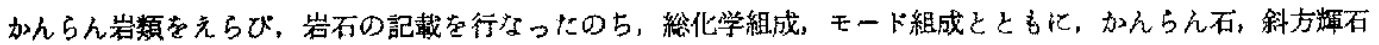
怙よび単斜輝石の化学組成劣報告した。造岩鉣物の化学的性質， $\mathrm{Fe}^{+2}-\mathrm{Mg}$ 分配などから，てれらのかんらん岩

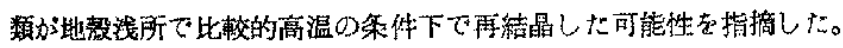

